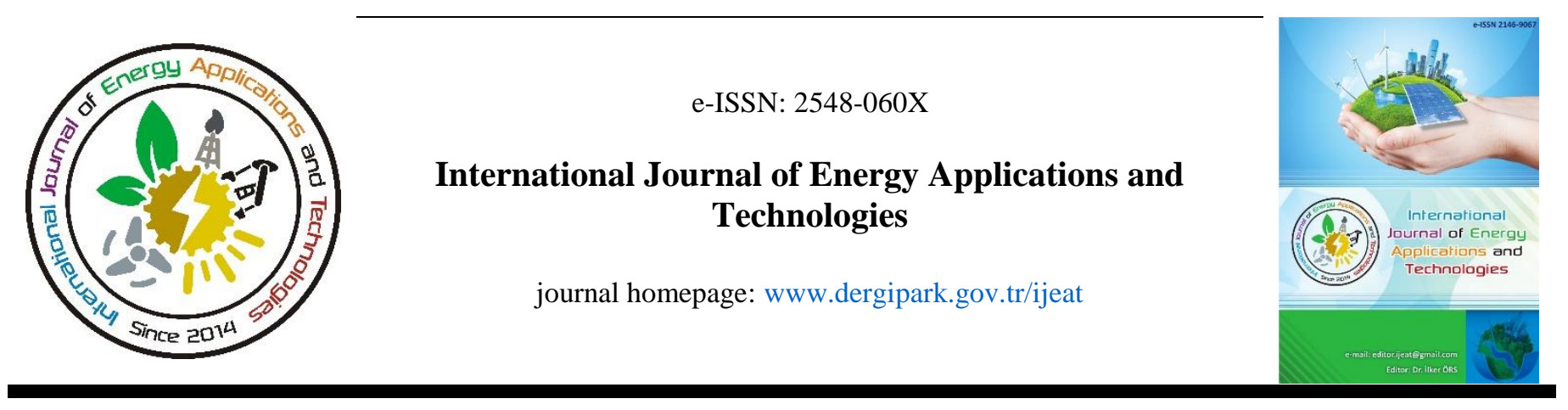

Original Research Article

\title{
Energy, environmental and enviroeconomic analysis of the use R134a/R1234yf (10/90) as replace to $R 134 a$ in a vapor compression cooling system
}

hosted by Turkish JournalPark

\author{
Ragıp Yıldırım ${ }^{1,2^{*}}$, Abdullah Yıldı2 \\ ${ }^{I}$ Prog. of Alt. Energy Sources Tech., Bucak Emin Gulmez Vocational Schoolof of Technical Sciences, Burdur Mehmet Akif Ersoy University, Burdur, Turkey \\ ${ }^{2}$ Mechanical Engineering Department, Faculty of Engineering, Uşak University, Usak Turkey
}

\author{
ARTICLE INFO \\ * Corresponding author \\ ryildirim@mehmetakif.edu.tr \\ Received July 15, 2020 \\ Accepted October 30, 2020 \\ Published by Editorial Board \\ Members of IJEAT \\ (C) This article is distributed by \\ Turk Journal Park System under \\ the CC 4.0 terms and conditions. \\ doi: 10.31593/ijeat.769962
}

\begin{abstract}
In this study, the use of R134a and R134a/R1234yf (10/90) refrigerants in a cooling system have been investigated theoretically. The energy, environmental and enviroeconomic analyzes of refrigerants have been performed for a cooling system. The energy performances of refrigerants have been made for different evaporator (between $-10^{\circ} \mathrm{C}$ and $5^{\circ} \mathrm{C}$ ) temperatures and a constant condenser $\left(35^{\circ} \mathrm{C}\right)$ temperature. The R134a/R1234yf (10/90) has a higher mass flow rate $(26.50 \%)$ than R134a. Because R134a/R1234yf (10/90) has a lower refrigerating effect (evaporator enthalpy difference) than R134a. The R134a/R1234yf (10/90) has slightly higher compressor energy consumption (nearly 2.94\%) than R134a, and so the COP of R134a has slightly (nearly $2.85 \%$ ) higher than R134a/R1234yf (10/90). When compared to R134a, it is seen that the R134a/R1234yf (10/90) significantly reduces discharge temperature (about 16\%). The environmental and enviroeconomic result values of R134a/R1234yf (10/90) are slightly higher than R134a. However, even the slight differences are significant to the evaluation of the environmental impact of refrigerants. It is seen that the wind energy source has the lowest environmental and enviroeconomic value and so the wind energy is the best environmentally friendly energy source according to the other energy sources.
\end{abstract}

Keywords: Energy; Environmental; Enviroeconomic; Global Warming; R134a/R1234yf mixture

\section{Introduction}

Many vapor compressing systems such as heating and cooling, domestic refrigeration, and hot water production used R134a as working fluid, in recent years. Even though ozone depletion potential (ODP) of R134a is zero, global warming potential (GWP) of this fluid is 1300. Therefore, R134a (hydrofluorocarbons (HFCs) was taken to the controlled greenhouse gas list with the Kyoto protocol (1997). The HFCs should be phased out according to the Kigali's amendment to the Montreal protocol (2016) [1].

There are some alternatives to replace R134a: (I) natural refrigerants (ammonia $\left(\mathrm{NH}_{3}\right)$, carbon dioxide $\left(\mathrm{CO}_{2}\right)$, etc.), (II) HFCs with low GWP (such as R32 and R152a), (III) hydrocarbons (HCs) and (IV) hydrofluorolefins (HFOs), R1234yf and R1234ze(E) [1,2]. Among all these options,
R1234yf is a good candidate for the alternative of R134a because the thermophysical properties of R1234yf and R134a are very similar. R1234yf has a low GWP ratio (less than 1) and zero ODP. However, it has low flammability [3]. R1234yf has some disadvantages when used in R134a systems, such as low flammability and insufficient cooling capacity[4,5]. To reduce those disadvantages of R1234yf and keep the GWP ratio low, refrigerants consisting of HFC/HFO binary mixtures have been developed recently (such as R513A and R450A). R513A refrigerant consists of mixing R134a/R1234yf by 44/56 percent by mass. R513A refrigerant is an azeotropic mixture. It has zero ODP and 573 GWP (about half of R134a) [6].

Meng et al. [7] experimentally examined both the heating and cooling performance of the refrigerant mixture 
R134a/R1234yf (11/89 by mass) in the air conditioning systems of cars. They stated that R134a/R1234yf refrigerant mixture had $4 \%$ to $9 \%$ lower cooling COP than R134a. In the case of heating, they stated that the COP value of the $\mathrm{R} 134 \mathrm{a} / \mathrm{R} 1234 \mathrm{yf}$ refrigerant mixture compared to R134a, this ratio varied between $4 \%$ and $16 \%$. This refrigerant mixture can be used as an alternative fluid to R134a in the vehicle cooling system. Aprea et al. [8] experimentally examined and compared the performance of refrigerants R134a, R1234yf and R134a/R1234yf (10/90 by mass) in the household refrigerator. They stated that the R134a/R1234yf mixture has similar thermophysical properties with R134a and consumes $16 \%$ less energy than R134a and 14\% less energy than R1234yf. They also stated that adding $10 \%$ of HFC134a to HFO1234yf, the mixture becomes non-flammable. In another study, Aprea et al. experimentally investigated energy and environmental analysis of refrigerants with low GWP ratios such as R134a, R1234yf, R1234ze (E), R134a/R1234yf (10/90 by mass), R134a/R1234ze (E) (10/90 by mass). They stated that R134a/R1234yf (10/90) reduced the emission value by $17 \%$ compared to R134a [8]. Lee et al. [9] examined the effects of R1234yf and R134a/R1234yf mixtures (5/95, $10 / 90,15 / 85$ mixing rates in mass) on COP, heating and cooling capacity, discharge temperatures, and stated that the R134a/R1234yf mixtures gave close results with R134a refrigerant. They also emphasized that R1234yf and $\mathrm{R} 134 \mathrm{a} / \mathrm{R} 1234 \mathrm{yf}$ mixtures need to charge more refrigerant (approximately 11\%) than R134a.

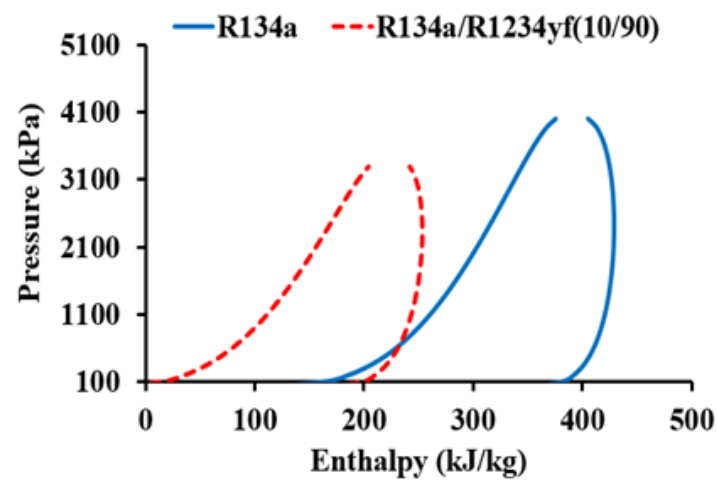

Fig. 1. Pressure - enthalpy diagram of refrigerants

Refrigerants with a low GWP are required to reduce the impact of vapor compressing systems on climate change. $\mathrm{R} 134 \mathrm{a} / \mathrm{R} 1234 \mathrm{yf}$ mixtures are thought to replace R134a in systems operating according to the vapor compressing cycle. $\mathrm{R} 134 \mathrm{a} / \mathrm{R} 1234 \mathrm{yf}$ mixtures can overcome particular of the drawbacks of pure refrigerants and improve thermophysical properties. In this study, investigated that the energy, environmental, and enviroeconomic analyses of a vapor compression refrigeration system for R134a and R134a/R1234yf (10/90). The pressure-enthalpy and pressure-temperature diagrams of refrigerants are given in Fig. 1 and Fig. 2, respectively. It is important to investigate environmentally friendly new generation refrigerants with low GWP and zero ODP. Therefore, this study could be made important contributions to the literature.

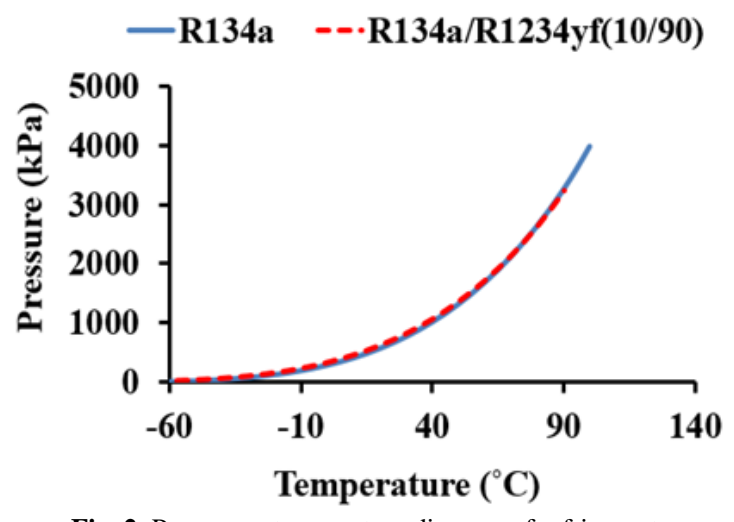

Fig. 2. Pressure - temperature diagram of refrigerants

\section{Materials and Methods}

In this study, a single-stage steam compression cooling system was used to compare the performances of R134a and R134a/R1234yf (10/90 by mass) refrigerants (Fig. 3). Acceptances made for the cooling system are shown in Table 1. Also, it is assumed that there is no pressure loss in the pipes and all elements of the system are steady-state flow.

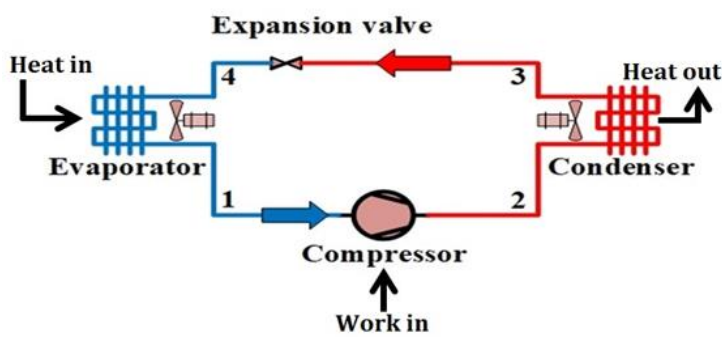

Fig. 3. The schematic diagram of the cooling system

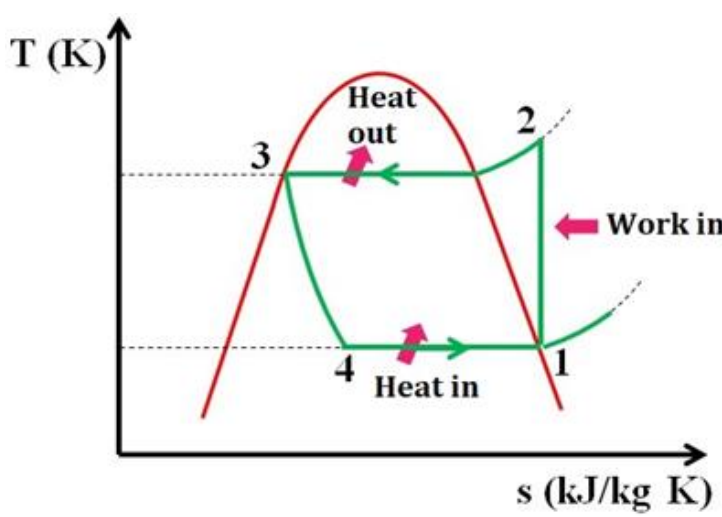

Fig. 4. T-s diagram of the cooling system

Table 1. Assumptions made for the system

\begin{tabular}{lc}
\hline Cooling capacity & $1 \mathrm{~kW}$ \\
Condenser temperature & $35^{\circ} \mathrm{C}$ \\
Evaporator temperature & $-10{ }^{\circ} \mathrm{C},-5^{\circ} \mathrm{C}, 0^{\circ} \mathrm{C}$ and $5{ }^{\circ} \mathrm{C}$ \\
Compressor isentropic efficiency & 0.70 \\
Superheating temperature & $5^{\circ} \mathrm{C}$ \\
Sub-cooling temperature & $5^{\circ} \mathrm{C}$ \\
The expansion valve is isenthalpic. & \\
\hline
\end{tabular}




\subsection{Energy analysis}

The energy analysis of the cooling system has made according to the first law of thermodynamics. The energy consumed of compressor ( $\left.\dot{\mathrm{W}}_{\text {comp. }}\right)$, the heat rejected from the condenser $\left(\dot{Q}_{\text {cond. }}\right)$, the heat taken from the evaporator $\left(\dot{Q}_{\text {evap. }}\right)$ and the coefficient of performance (COP) for cooling mode are given in Eq.1- Eq.4, respectively. Where $h$ shows the enthalpy value of the related reference point $(\mathrm{kJ} / \mathrm{kg})$ and $\dot{\mathrm{m}}_{\mathrm{R}}$ is the mass flow rate of refrigerant $(\mathrm{kg} / \mathrm{s})$.

$$
\begin{aligned}
& \dot{\mathrm{W}}_{\text {comp. }}=\dot{\mathrm{m}}_{\mathrm{R}}\left(\mathrm{h}_{2}-\mathrm{h}_{1}\right) \\
& \dot{\mathrm{Q}}_{\text {cond. }}=\dot{\mathrm{m}}_{\mathrm{R}}\left(\mathrm{h}_{2}-\mathrm{h}_{3}\right) \\
& \dot{\mathrm{Q}}_{\text {evap. }}=\dot{\mathrm{m}}_{\mathrm{R}}\left(\mathrm{h}_{1}-\mathrm{h}_{4}\right) \\
& \text { COP }=\frac{\dot{\mathrm{Q}}_{\text {evap. }}}{\dot{\mathrm{W}}_{\text {comp. }}}
\end{aligned}
$$

\subsection{Environmental analysis}

The environmental analysis is calculated by Equation 5 [10].

$$
\mathrm{x}_{\mathrm{CO}_{2}}=\mathrm{y}_{\mathrm{CO}_{2}} \dot{\mathrm{E}}_{\mathrm{in}} \mathrm{t}_{\text {working }}
$$

$\mathrm{x}_{\mathrm{CO}_{2}}$ is the greenhouse releasing $\left(\mathrm{CO}_{2}\right)$ in a period of time $\left(\mathrm{kgCO}_{2} /\right.$ time), $\mathrm{y}_{\mathrm{CO}_{2}}$ is the emission value for the energy option $\left(\mathrm{kgCO}_{2} / \mathrm{kWh}\right), \dot{\mathrm{E}}_{\mathrm{in}}$ is the energy rate of the energy option (kW) and $t_{\text {working }}$ is the working time of the system (h / time).

\subsection{Enviroeconomic analysis}

The enviroeconomic analysis can be calculated by Equation $6[10]$.

$$
\mathrm{C}_{\mathrm{CO}_{2}}=\mathrm{c}_{\mathrm{CO}_{2}} \mathrm{x}_{\mathrm{CO}_{2}}
$$

$\mathrm{x}_{\mathrm{CO}_{2}}$ is the result of environmental analysis $\left(\mathrm{kgCO}_{2} /\right.$ time), $\mathrm{c}_{\mathrm{CO}_{2}}$ is the $\mathrm{CO}_{2}$ emission price $\left(\$ / \mathrm{kgCO}_{2}\right)$ and $\mathrm{C}_{\mathrm{CO}_{2}}$ is enviroeconomic analysis ( $\$$ / time). The $\mathrm{CO}_{2}$ emission price was taken as $0.0145\left(\$ / \mathrm{kgCO}_{2}\right)[10]$.

Table 2. $\mathrm{CO}_{2}$ emission value of the energy sources used for electricity generations [11]

\begin{tabular}{cc}
\hline $\begin{array}{c}\text { Electricity generation } \\
\text { source }\end{array}$ & $\begin{array}{c}\mathbf{C O}_{\mathbf{2}} \text { Emission value } \\
\left(\mathbf{k g C O} \mathbf{C O}_{2} / \mathbf{k W h}\right)\end{array}$ \\
\hline Hydro & $0.0037-0.237$ \\
Wind & $0.0097-0.1237$ \\
Solar thermal & $0.0136-0.202$ \\
Nuclear & 0.0242 \\
Biomass & $0.035-0.178$ \\
Solar PV & $0.0534-0.250$ \\
Coal & 0.9753 \\
Oil & 0.7421 \\
\hline
\end{tabular}

Required electricity for the cooling systems can be provided from many energy sources. There are some of the $\mathrm{CO}_{2}$ emission values for electricity generation sources in the literature (Table 2). In this study, hydro, wind, solar PV, coal, oil, and nuclear were selected as energy options. The $\mathrm{CO}_{2}$ emission values of the hydro, wind, solar PV, coal, oil and nuclear are $0.1204 \mathrm{kgCO}_{2} / \mathrm{kWh}, 0.0667 \mathrm{kgCO}_{2} / \mathrm{kWh}$, $0.3034 \quad \mathrm{kgCO}_{2} / \mathrm{kWh}, \quad 0.9753 \quad \mathrm{kgCO}_{2} / \mathrm{kWh}, \quad 0.7421$ $\mathrm{kgCO}_{2} / \mathrm{kWh}$ and $0.1078 \mathrm{kgCO}_{2} / \mathrm{kWh}$, respectively. It is assumed that the working period of the cooling system is 360 hours /month.

\section{Results and Discussion}

In this study, the performances of R134a and R134a/R1234yf (10/90) mixture for the cooling system have been investigated. The mass flow rate of refrigerant, refrigerating effect, compressor energy consumption, COP value, and discharge temperature, have analyzed and compared for the cooling system. Also, the environmental and enviroeconomic analyzes of both refrigerant were made.

\section{QR134a $\square$ R134a/R1234yf(10/90)}

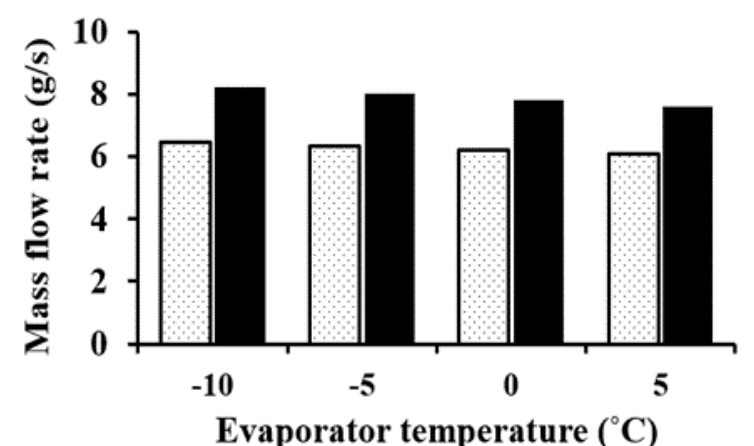

- R134a/R1234yf(10/90)

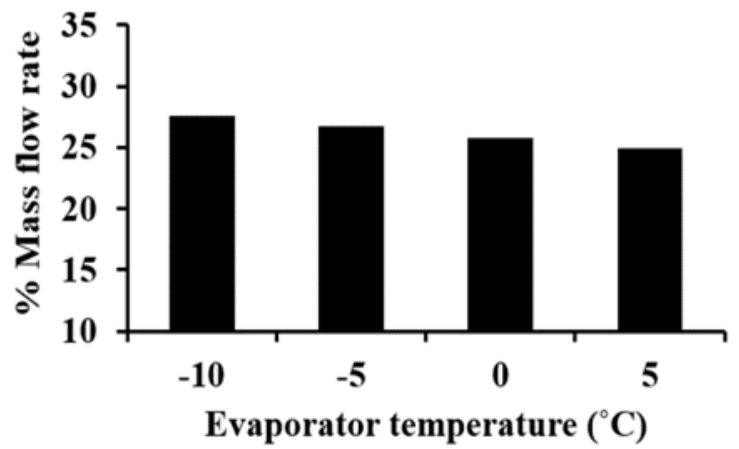

Fig. 5. Mass flow rate and comparison of mass flow rate relative to R134a

The mass flow rate of refrigerants is given in Fig. 5 for different evaporator temperatures. At the evaporator temperatures of $-10{ }^{\circ} \mathrm{C},-5^{\circ} \mathrm{C}, 0{ }^{\circ} \mathrm{C}$ and $5{ }^{\circ} \mathrm{C}$, the mass flow rate of R134a are 6.44, 6.32, 6.20 and $6.08 \mathrm{~g} / \mathrm{s}$ respectively, while the flow rate of R134a/R1234yf (10/90) are 8.22, 8.00, 7.80 and $7.60 \mathrm{~g} / \mathrm{s}$. As seen Fig. 5, the R134a/R1234yf (10/90) has higher mass flow rate $(25 \%-28 \%)$ than R134a. This is because R134a/R1234yf (10/90) has lower refrigerating effect (evaporator enthalpy difference) $(20 \%-22 \%)$ than R134a (Fig. 6).

The compressor energy consumption of $\mathrm{R} 134 \mathrm{a}$ and R134a/R1234yf (10/90) is given in Fig. 7 for different evaporator temperatures. R134a/R1234yf (10/90) has slight 
higher compressor energy consumption $(2.18 \%-3.69 \%)$ than R134a. Though R134a/R1234yf (10/90) has a higher mass flow rate than R134a, compressor energy consumption of it is almost the same as R134a. This situation is related to the thermophysical properties of refrigerants.

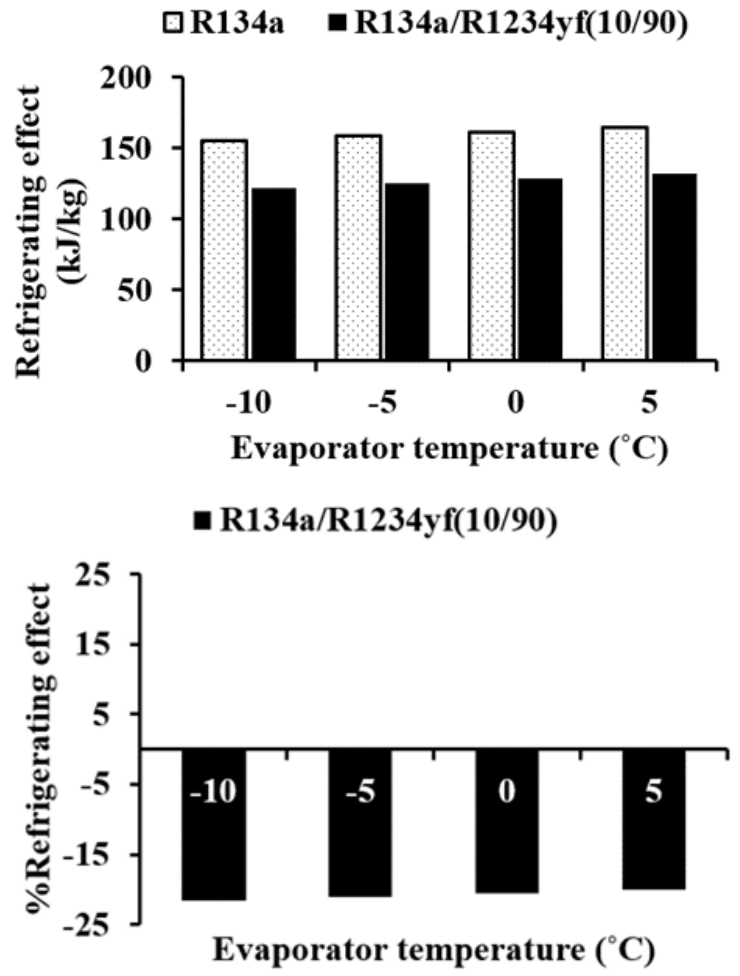

Fig. 6. Refrigerating effect and comparison of refrigerating effect relative to $\mathrm{R} 134 \mathrm{a}$

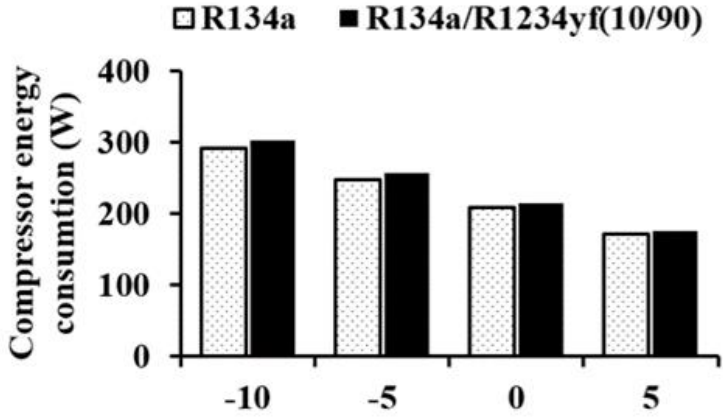

Evaporator temperature $\left({ }^{\circ} \mathrm{C}\right)$

- R134a/R1234yf(10/90)

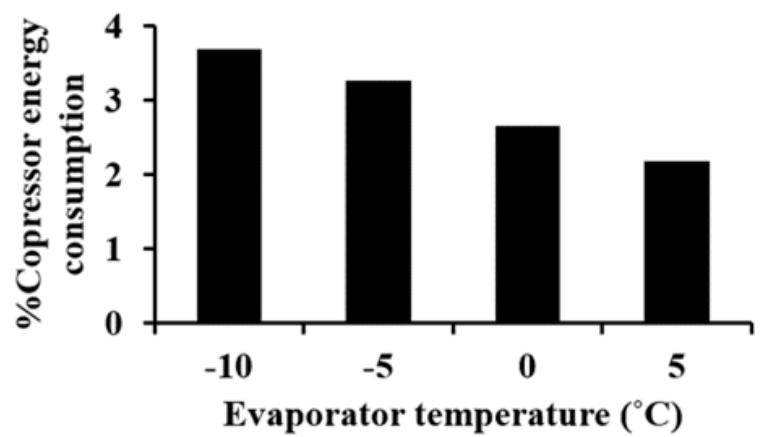

Fig. 7. Compressor energy consumption and comparison of compressor energy consumption relative to $\mathrm{R} 134 \mathrm{a}$
The COP of R134a and R134a/R1234yf (10/90) is given in Fig. 8. At the evaporator temperatures of $-10{ }^{\circ} \mathrm{C},-5^{\circ} \mathrm{C}, 0{ }^{\circ} \mathrm{C}$ and $5{ }^{\circ} \mathrm{C}$, the COP of R134a are $3.42,4.02,4.78$ and 5.79 respectively, while the COP of R134a/R1234yf (10/90) are 3.30, 3.89, 4.65 and 5.67. As seen in Fig. 8, when Compared COP of refrigerants R134a has slightly higher (2.13\% $3.56 \%$ ) COP than R134a/R1234yf (10/90).
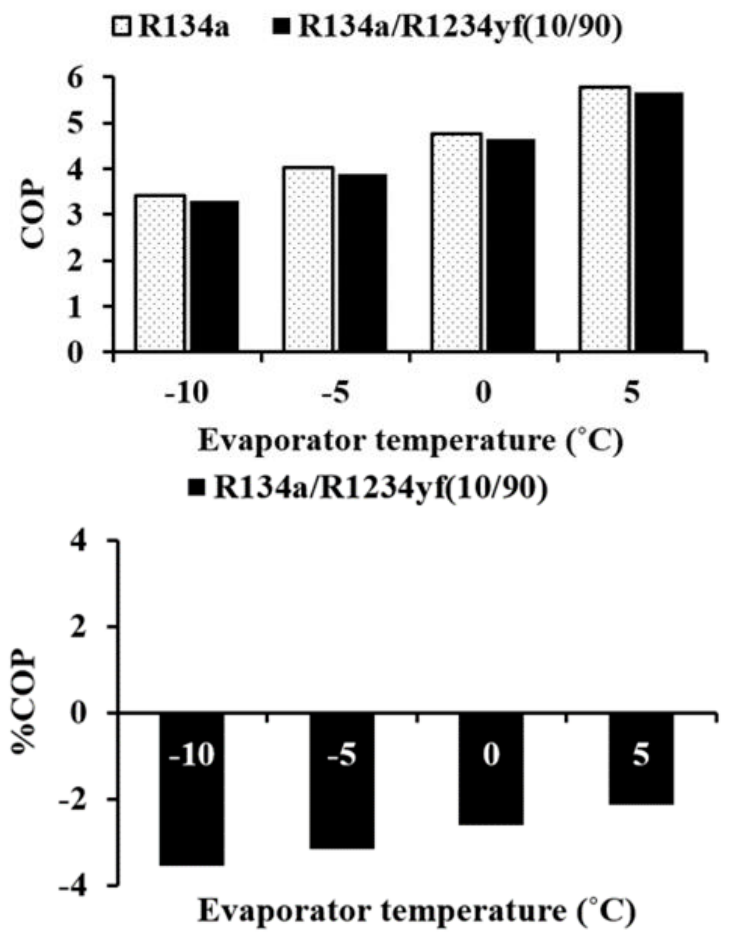

Fig. 8. COP and comparison of COP relative to R134a

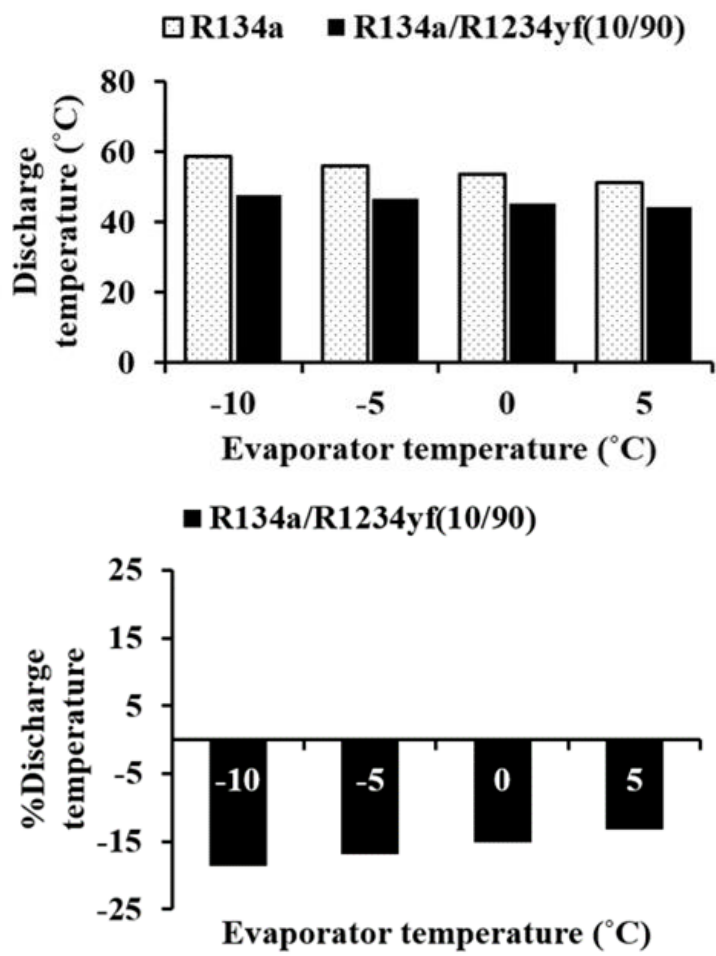

Fig. 9. Discharge temperature and comparison of discharge temperature relative to $\mathrm{R} 134 \mathrm{a}$ 
The compressor discharge temperature is one of the significant parameters to select refrigerants as a working fluid. When it is too high, it may cause lubricant degradation and so compressor breakdown. The discharge temperature of refrigerants is given in Fig. 9. The R134a has higher (13.30\% - $18.71 \%$ ) discharge temperature than R134a/R1234yf (10/90).
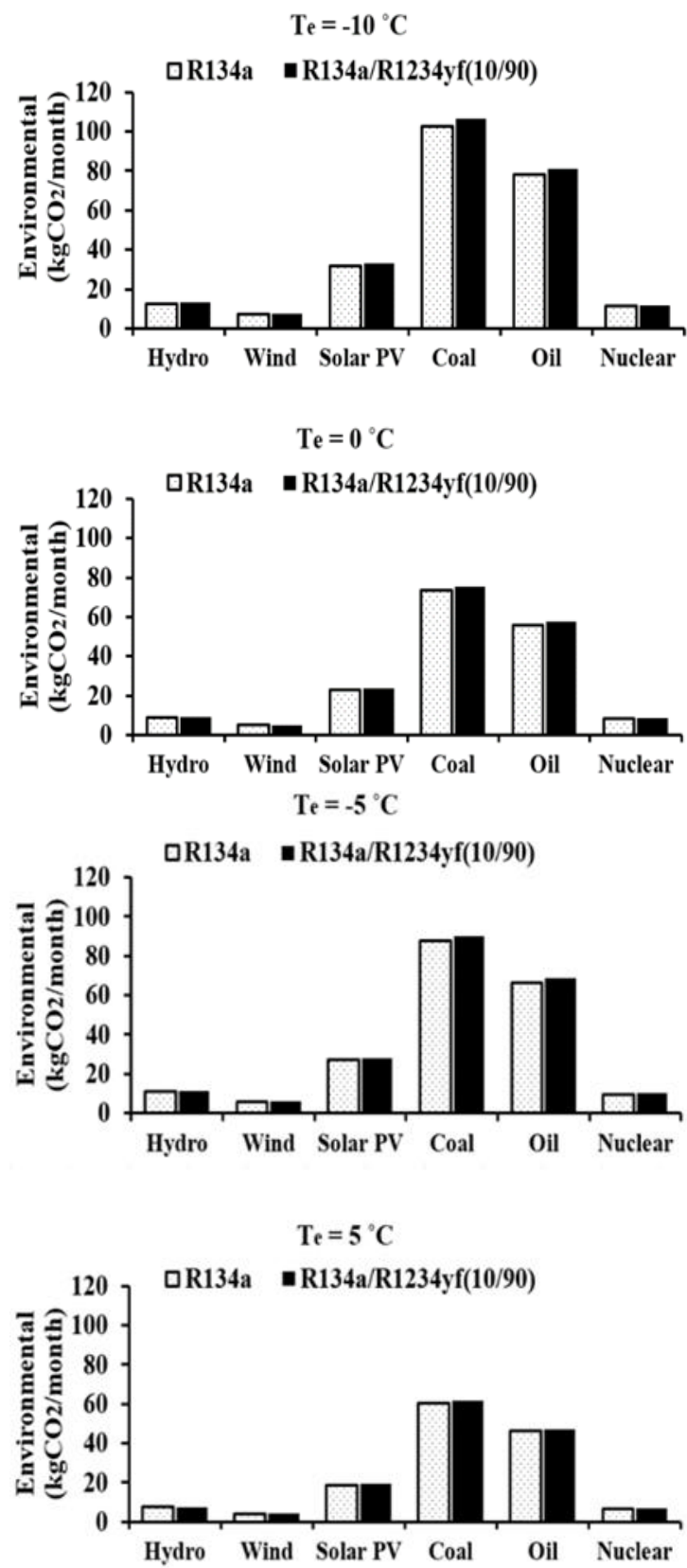

Fig. 10. Environmental results for different evaporator temperatures and energy sources

The environmental analysis of the R134a and $\mathrm{R} 134 \mathrm{a} / \mathrm{R} 1234 \mathrm{yf}$ (10/90) for the different energy sources is given in Fig. 10. For evaporator temperature $-10{ }^{\circ} \mathrm{C}$ and hydro, wind, solar PV, coal, oil, and nuclear energy sources: the environmental analysis of R134a is $12.66,7.01,31.90$, 102.54, 78.02 and $11.33 \mathrm{kgCO}_{2} /$ month, respectively. Under same conditions the environmental analysis of
$\mathrm{R} 134 \mathrm{a} / \mathrm{R} 1234 \mathrm{yf}(10 / 90)$ is $13.13,7.27,33.07,106.32,80.90$ and $11.75 \mathrm{kgCO}_{2} /$ month. The environmental result values of R134a/R1234yf(10/90) are slightly higher than R134a. However, even the slight differences are significant to perform the environmental evaluation effectively. Also, it is seen that the wind energy source has the lowest environmental value and so, the wind energy is the best environmental energy source according to the other energy sources.
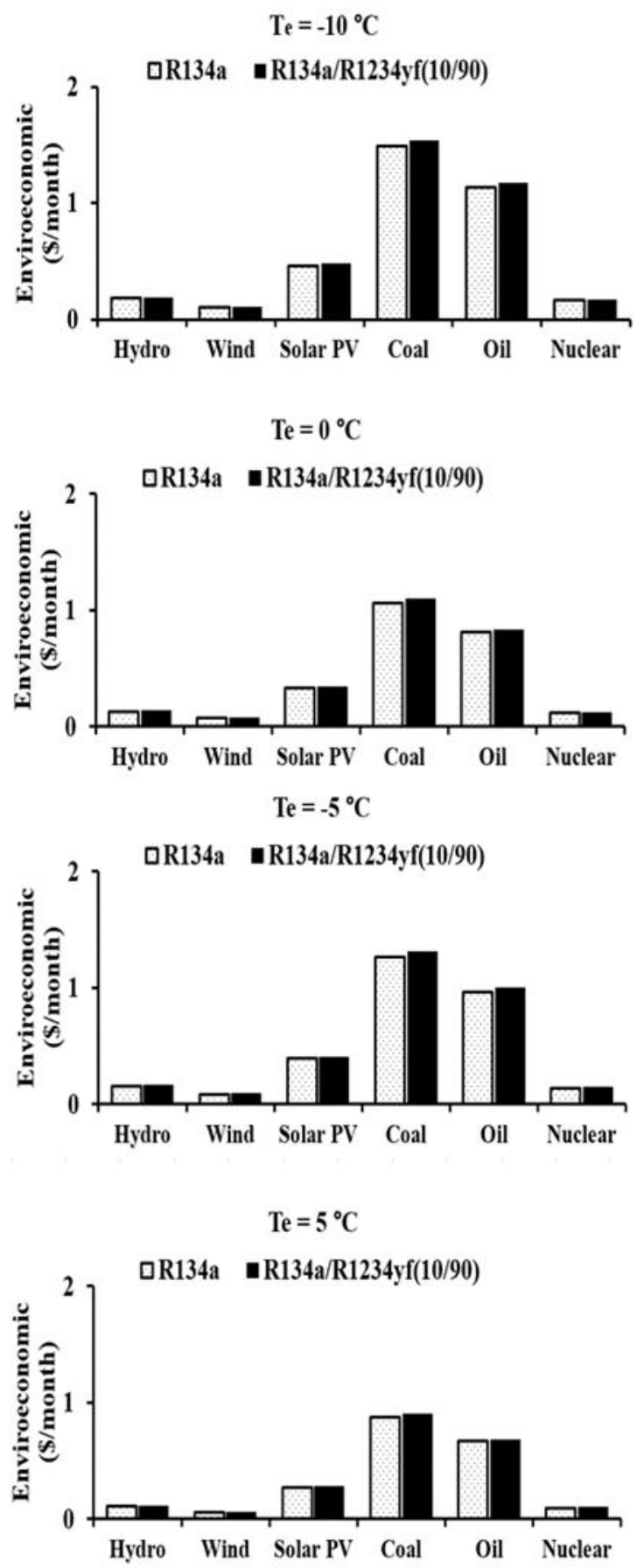

Fig. 11. Enviroeconomic results for different evaporator temperatures and energy sources

The enviroeconomic analysis of the R134a and $\mathrm{R} 134 \mathrm{a} / \mathrm{R} 1234 \mathrm{yf}$ (10/90) for the different energy sources is 
given in Fig. 11. For evaporator temperature $-10{ }^{\circ} \mathrm{C}$ and hydro, wind, solar PV, coal, oil, and nuclear energy sources: the envieconomic analysis of $\mathrm{R} 134 \mathrm{a}$ are $0.18,0.10,0.46$, $1.49,1.13$, and $0.16 \$ /$ month, respectively. Under same conditions the enviroeconomic analysis of R134a/R1234yf (10/90) are $0.19,0.11,0.48,1.54,1.17$ and $0.17 \$ /$ month. The enviroeconomic results of both refrigerants are very small due to both of are used in the small scale cooling system. The wind energy has the lowest envireconomic values for both of refrigerants.

\section{Conclusions}

The energy, environmental, and enviroeconomic analysis of the using R134a/R1234yf (10/90) as replace to R134a in a vapor compression cooling system have been presented and discussed. The following main conclusions can be drawn from this study:

- The R134a/R1234yf (10/90) has a higher mass flow rate than $\mathrm{R} 134 \mathrm{a}$, Because of the R134a/R1234yf (10/90) has lower refrigerating effect than R134a.

- The R134a/R1234yf (10/90) has slightly higher compressor energy consumption (nearly 2.94\%) than R134a.

- $\quad$ The R134a has slightly higher (2.85\%) COP than R134a/R1234yf (10/90).

- The R134a/R1234yf (10/90) has lower (about 16\%) discharge temperature than R134a.

- The conventional energy sources (coal and oil) are the worst options among the energy sources according to the environmental and eviroeconomic analyzes. But, the oil would be a better choice, if there was an obligation to choose between oil and coal. In general, renewable energy sources and nuclear energy are better options than conventional energy sources. The wind energy, which is a renewable energy source, is the best choice among all energy sources.

- The environmental and enviroeconomic analyzes give helpful information related to $\mathrm{CO}_{2}$ emission and $\mathrm{CO}_{2}$ prices in a certain period of time. So, it can succeed in that reduction and economic management of greenhouse gases owing to the environmental and enviroeconomic analyzes.

\section{Acknowledgment}

The authors wish to thank all who assisted in conducting this research.

\section{ORCID}

Ragıp Yildırım

Abdullah Yildız

\section{References}

[1] Akyüz A.Ö., Kumaş, K., İnan, O. and Güngör, A. 2019. Determination of carbon footprint from airplanes:Muğla province airports. Academic Platform Journal of Engineering and Science, 7(2), 291-297.

[2] Kumaş, K, Akyüz, A. Ö, Zaman, M. and Güngör A. 2019. Carbon footprint determination for a sustainable environment: MAKÜ Bucak school of health example. El-Cezerî Journal of Science and Engineering, 6(1),108-117.

[3] Pabon, J. J. G., Khosravi, A., Belman-Flores, J. M., Machado, L. and Revellin, R. 2020. Applications of refrigerant R1234yf in heating, air conditioning and refrigeration systems: A decade of researches. International Journal of Refrigeration, 118, 104-113.

[4] Zhang, L., Zhao, J., Yue, L., Zhou, H. and Ren, C. 2019. Cycle performance evaluation of various R134a/hydrocarbon blend refrigerants applied in vapor-compression heat pumps. Advances in Mechanical Engineering, 11, 1-14.

[5] Feng, B., Yang, Z. and Zhai, R. 2018. Experimental study on the influence of the flame retardants on the flammability of R1234yf. Energy, 143, 212-218.

[6] Sethi, A., Vera Becerra, E. and Yana Motta, S. 2016. Low GWP $\mathrm{R} 134$ a replacements for small refrigeration (plug-in) applications. International Journal of Refrigeration, 66, 64-72.

[7] Mota-Babiloni, A., Navarro-Esbrí, J., Barragán, Á., Molés, F. and Peris, B. 2014. Drop-in energy performance evaluation of $\mathrm{R} 1234 \mathrm{yf}$ and R1234ze(E) in a vapor compression system as R134a replacements. Applied Thermal Engineering, 71, 259-265.

[8] Mota-Babiloni, A., Belman-Flores, J. M., Makhnatch, P., Navarro-Esbrí, J. and Barroso-Maldonado, J. M. 2018. Experimental exergy analysis of R513A to replace R134a in a small capacity refrigeration system. Energy, 162, 99-110.

[9] Meng, Z., Zhang, H., Lei, M., Qin, Y. and Qiu, J. 2018. Performance of low GWP R1234yf/R134a mixture as a replacement for R134a in automotive air conditioning systems. International Journal of Heat and Mass Transfer, 116, 362-70.

[10] Aprea, C., Greco, A. and Maiorino, A. 2017. An experimental investigation of the energetic performances of HFO1234yf and its binary mixtures with HFC134a in a household refrigerator. International Journal of Refrigeration, 76, 109-117.

[11] Lee, Y., Kang, D. G. and Jung, D. 2013. Performance of virtually non-flammable azeotropic HFO1234yf/HFC134a mixture for HFC134a applications. International Journal of Refrigeration, 36, 1203-1207.

[12] Caliskan H. 2017. Energy, exergy, environmental, enviroeconomic, exergoenvironmental (EXEN) and exergoenviroeconomic (EXENEC) analyses of solar collectors. Renewable and Sustainable Energy Reviews, 69, 488-492.

[13] Kumaş, K., Akyüz, A. Ö. and Güngör, A. 2019. The determination of carbon footprint for higher education units of Burdur Mehmet Akif Ersoy University in Bucak campus. Nigde Omer Halisdemir University Journal of Engineering Sciences, 8(2), 1277-1291.

[14] Goel, V., Bhat, I. K. and Prakash, R. 2009. LCA of renewable energy for electricity generation systems - a review. Renewable and Sustainable Energy Reviews, 13(5), 1067-1073. 